\title{
Aquatic environments in the One Health context: modulating the antimicrobial resistance phenomenon
}

Ambientes aquáticos no contexto One Health: modulação do fenômeno da resistência aos antimicrobianos

\author{
Juliana Alves Resende ${ }^{1}$ (D), Vânia Lúcia da Silva² (D) and Claudio Galuppo Diniz ${ }^{2 *}$
}

\author{
${ }^{1}$ Departamento de Farmácia e Nutrição, Universidade Federal do Espírito Santo - UFES, Campus \\ Alegre, Alto Universitário, s/n, Guararema, CEP 29500-000, Alegre, ES, Brasil \\ ${ }^{2}$ Departamento de Parasitologia, Microbiologia e Imunologia, Instituto de Ciências Biológicas, \\ Universidade Federal de Juiz de Fora - UFJF, Rua José Lourenço Kelmer, s/n, Campus \\ Universitário, CEP 36036-900, Juiz de Fora, MG, Brasil \\ *e-mail: claudio.diniz@icb.uff.br
}

Cite as: Resende, J.A., Silva, V.L. and Diniz, C.G. Aquatic environments in the One Health context: modulating the antimicrobial resistance phenomenon. Acta Limnologica Brasiliensia, 2020, vol. 32, e102.

\begin{abstract}
From an anthropocentric perspective, aquatic environments are important to maintain health and survival, however, as they are sometimes managed based on misconception, they are considered a convergent pathway for anthropogenic residues and sanitation. Thus, it is observed that these ecosystems have been threatened by chemical pollution due to xenobiotics, especially from a more contemporary approach, by the selective pressure associated with antimicrobials. There are several studies that report the enrichment of antimicrobial resistant bacteria and mobilizable antimicrobial resistance genes in aquatic and adjacent ecosystems. From the perspective of the emerging and reemerging number of diseases related to the interplay of human, animal, and environmental factors, a new conception arose to address these issues holistically, which is known as the One Health approach. Scientific and political discourse on this conception should lead to effective action plans for preventing and controlling the spread of infectious diseases in open environment, including those impacted by anthropogenic activities. Therefore, nowadays, discussions on antimicrobial resistance are becoming broader and are requiring a multi-disciplinary view to address health and environmental challenges, which includes aquatic environment management. Water may represent one of the most important ecosystems for the in antimicrobial resistance phenomenon that arises when a dynamic and singular microbial community may be influenced by several characteristics. As antimicrobial substances do not all degrade at the same time under the same treatment, strategies concerning their removal from the environment should consider their individualized chemical characteristics.
\end{abstract}

Keywords: One Health; antimicrobial resistance genes; dissemination routes; aquatic environment; human activities.

Resumo: Em uma perspectiva antropocêntrica, os ambientes aquáticos são importantes para manutenção da saúde e da sobrevivência, entretanto, gerenciados muitas vezes de maneiras equivocadas, são considerados uma via convergente para os resíduos gerados por atividades humanas e saneamento. Desta forma, observa-se que esses ecossistemas têm sido ameaçados pela poluição química devido a xenobióticos, sobretudo em uma abordagem mais contemporânea, pela pressão seletiva associada aos antimicrobianos. Vários estudos têm reportado o enriquecimento de bactérias resistentes aos antimicrobianos e genes mobilizáveis relacionados a esse fenômeno em ambientes aquáticos e ecossistemas adjacentes. Do ponto de vista das doenças emergentes e reemergentes relacionadas à 
interação de fatores humanos, animais e ambientais, surgiu uma nova concepção para abordar, em uma visão holística, essas questôes, conhecidas como abordagem de saúde única (One Health). Discussóes científicas e políticas nessa concepção devem levar a planos de ação eficazes para prevenir e controlar a disseminaçáo de doenças infecciosas em ambiente aberto, incluindo aquelas afetadas por atividades antropogênicas. Portanto, hoje em dia, as discussóes sobre resistência antimicrobiana estão se tornando mais amplas e exigindo uma visão multidisciplinar para enfrentar os desafios de saúde e ambientais, que incluem a gestão do ambiente aquático. A água pode ser um dos ecossistemas mais importantes no fenômeno da resistência antimicrobiana que surge quando uma comunidade microbiana dinâmica e singular pode ser influenciada por várias características. Como as substâncias antimicrobianas não são degradadas, ao mesmo tempo sob um mesmo tratamento, as estratégias relativas à sua remoção do meio ambiente devem considerar suas características químicas individuais.

Palavras-chave: One Health; genes de resistência a antimicrobianos; vias de disseminação; ambiente aquáticos; atividades humanas.

\section{Introduction}

An ecosystem is a set of different communities of higher organisms and microorganisms that interact with each other and with the environment, constituting a stable, balanced, and self-sustained system. The aquatic ecosystem plays one of the most important integrative roles, as it is an essential natural resource, either as a biochemical component reservoir or as an interconnection pathway between several other ecosystems and convergent to several species ( $\mathrm{Na}$ et al., 2018).

From an anthropocentric perspective, the aquatic environment is important to maintain health and survival, for example, by providing food and allowing its productivity in both agricultural and industrial levels. However, anthropogenic waste and sanitation are important sources of pollution for aquatic ecosystems (Berglund, 2015). Thus, due to the excessive human activity and environmental degradation, aquatic ecosystems are being threatened, especially by chemical pollution due to the impacts of xenobiotic discharge (Berglund, 2015; Na et al., 2018). The indiscriminate use of xenobiotics, such as antimicrobial drugs, biocides, and toxic metals resulted in the emergence of classical multi-drug resistant putative pathogens (Resende et al., 2012).

In this regard, the term One Health has gained space in scientific discussions dealing with epidemiological issues. The origins of the One Health approach are based on the mutual dependency of humans and animal and the recognition that they share, not only the same environment, but also many health threats such as infection diseases (Collignon \& Mcewen, 2019). Since the late 1990s, numerous endemic and/or neglected zoonoses were transmitted between humans and animals. It has been estimated that at least $60 \%$ of human diseases and $60-75 \%$ of new emerging diseases are multi-host zoonoses (Webster et al., 2016). Thus,
One Health is related to the integrative view and management considering human health, animal health, and environment, as well as adoption of effective public policies to prevent and control diseases. The approach also includes the need of discussions aimed at solutions at the local, national, and global scale, which might include food safety, zoonosis, and antimicrobial-resistance control (Ogawa et al., 2019; Sanderson et al., 2019). From the One Health perspective, the antimicrobial resistance problem relates to human behavior, which includes, as a matter of fact, chemical pollution (xenobiotics) discharge in the open environments by different routes, with critical consequences considering for both human and animal health. In this regard, there is widespread expectation for the rise of comprehensive ecological studies to map the problem and lead to understanding of the main related impacts, since several pathogenic bacteria and their resistance genes have environmental origins (Rousham et al., 2018).

Antimicrobial resistance is a global public health problem. Since they were discovered, antibiotics have been used in human and veterinary medicine, in therapy, human prophylaxis, and in animal health as prophylaxis and growth promoters (Marti et al., 2014; Van Boeckel et al., 2015; Gonzalez Ronquillo \& Angeles Hernandez, 2017). Thus, the selective pressure exerted by its constant and often inadequate use has resulted in the emergence of multi-resistant bacteria that no longer respond to traditional therapies. The World Health Organization considers drug resistance a global public health problem and concerns about their use are an essential part of global health. Data show that more than 700,000 people die from untreated infections due to antimicrobial chemotherapy failure each year around the world, and if this pattern stays uncontrolled, by 2050, infections related to drug-resistant bacteria are 
estimated to seize around 10 million lives a year (O’Neill, 2014; Ogawa et al., 2019).

Considering that most antibiotics administered to humans and animals are excreted unchanged into the environment (sewage, hospital waste, livestock and aquaculture discharges, and agricultural run-off), concerns about the potential impact of antibiotic residues in the aquatic environment keep growing in recent years (Gros et al., 2012; Manyi-Loh et al., 2018). The phenomenon has reached ecological importance and goes beyond the risks associated with therapeutic failures in human health, due to the ease of mobilization and dissemination of genetic markers. In this context, human activities of agriculture and livestock are also relevant, as are their related microbiomes (soil and water) (Zhang et al., 2009; Marti et al., 2014; Colombo et al., 2017).

The aquatic environment is doubly associated with the spread of antimicrobial resistance, due to its role as a convergent ecosystem being a natural source of antimicrobial resistance genes (ARG), including those harbored by both commensal and pathogenic bacteria. Thus, the aquatic environment itself is a large recipient of antibiotic-resistant bacteria that come from different effluents and, not only accumulate in this environment, but also spread through different niches (Manaia et al., 2016). The intensification of anthropogenic activities has increased the prevalence of antibiotic-resistant bacteria and their ARG. According to the literature, it has been over a decade since it has been difficult to find a natural environment where antibiotics of medical relevance and human and animal clinical practice cannot be detected (Zhang et al., 2009). In this way, both water and sediment will play a fundamental role in the selection, evolution, and spread of bacteria and bacteria-harboring antimicrobial resistance genes.

In Brazil, the aquatic environment has been neglected in the action plans and regulations used to address antimicrobial resistance, although the phenomenon has already been discussed in scientific literature. Effluents from urban, hospital, and animal farm wastewater have been shown to harbor significant levels of antimicrobial resistant bacteria in aquatic ecosystems, which is related to the overuse and misuse of antimicrobial agents (Resende et al., 2012; Magalhães et al., 2016; Conte et al., 2017). Adding to that, as a mitigation strategy to avoid environmental pollution with cattle manure and as a recycling strategy, its agricultural application as biofertilizer from medicated animals could lead to the terrestrial accumulation of antimicrobial residues and antimicrobial-resistant bacteria (Heuer et al., 2011; Resende et al., 2014; Bastos et al., 2018).

\section{Aquatic and Terrestrial Ecosystems: Interplay in Enrichment and Dissemination of Antibiotic Resistance Genes}

Considering the widespread environmental distribution of antimicrobial resistance and its consequences for human and animal medicine, which is widely discussed, anthropogenic activities are particularly relevant. According to the literature, ecology of antimicrobial resistance is related to different environmental reservoirs, for which anthropogenic activities may play an important role as feeding source (Resende et al., 2014; Berglund, 2015; Na et al., 2018). From this perspective, studies have shown that resistant bacteria strains isolated from humans, animals, and aquatic and terrestrial environments may harbor the same types of gene sequences and/or had identical plasmid-borne resistance genes, which might suggest that the environmental resistant-bacteria are potentially transmitted to humans (Ewers et al., 2012; Schauss et al., 2015).

Depending on the antibiotic class, up to $80 \%$ of the antibiotics that are in widespread use in both human and animal medicine is released into the open environment in its active form, by excretion via bodily fluids and excrement, such as urine, sweat, and feces, but also by intentional or accidental environmental discharge. In this regard, there is a need for improved understanding of the impacts of human activities on antibiotic resistance development, a part of disease treatment that also includes pharmaceutical manufacturing waste, domestic and agricultural waste releases into the environment, and the influence of poor sanitation and unsafe water supplies.

There are emerging concerns that the so called anthropogenic impacts are changing environmental reservoirs of resistance genes, which may increase the selection of resistance genes into clinically relevant pathogens. For example, as wastewater treatment, drug manufacturing, and agricultural effluents release massive amounts of antibiotic residues, resistant bacteria may be selected, not only in open environment, but also in the digestive tracts of humans and animals as a biological consequence (D'Costa et al., 2006). Adding to that, exposure of bacteria to antibiotics or drug-resistant microorganisms in an open environment may 
accelerate the evolution of resistance, increase the abundance and distribution of resistance genes within the resistome that is critical to the development of clinical resistance, and increase exchange of antibiotic resistance genes between bacteria (Finley et al., 2013).

That said, it is reasonable to identity different ways in which antimicrobials or xenobiotic usage may contribute to the selective pressure imposed towards selection of resistant-bacteria and/or enrichment of genetic determinants of drug resistance in different situations: (i) treatment of infectious diseases at both nosocomial and community levels; (ii) therapeutic or prophylactic use of antimicrobials and other chemical substances as food additives and agricultural defensives in activities related to animal husbandry, aquaculture, and plant production; and (iii) at the industrial level, often related to accidental and intentional release of antimicrobials and other xenobiotics in to the environment (Resende et al., 2012; Andersson \& Hughes, 2014; Berglund, 2015). The soil and aquatic ecosystems are, in turn, important in this scenario, allowing the widespread selective pressure imposed. As a whole, this environmental network may contribute to the global movement of antibiotic resistance genes and determinants, and thus it is important to consider antibiotic resistance within the One Health concept, which might provide a global strategy for expanding interdisciplinary collaboration and communication (Finley et al., 2013; Andersson \& Hughes, 2014; Berglund, 2015; Karkman et al., 2019).

Currently, livestock activities are very important in Brazil, from both economical and socio-cultural perspectives, with approximately 222 million head of cattle and 40 thousand head of pigs, among other farmed species (Brasil, 2018). The current activity expansion has, as its main directives, a high animal density per farmed area, aiming to meet the internal and external needs of meat consumption, trade and profit along their derivative such as dairy industry. Thus, intensification of livestock production has been accompanied by higher risks of disease and disease transmission, with intensification of antimicrobial drugs and other antimicrobial substances use to increase profit. According to the literature, the average antimicrobial consumption in livestock per capita varies with species, and a range of $45 \mathrm{mg} / \mathrm{kg}$ was associated with cattle farms (Van Boeckel et al., 2015). The authors state, also, that back in 2010, Brazil was the third consumer of antimicrobial agents in food animal production, and an increase, nearly double in their consumption rate and up to seven times the projected population growth in Brazil, Russia, India, China, and South Africa, is estimated.

Overall, the use of antimicrobial agents in cattle farms is recommended to treat diseased animals. However, as a controversial issue, they are widely used, mainly in intensive systems, to treat animals that do not exhibit clinical signs of disease. Adding to that, administration of these compounds as prophylaxis or growth promoters may frequently occur in both therapeutic and sub-therapeutic levels offered along with water and food (Brown et al., 2017; Manyi-Loh et al., 2018).

Even though most of the administered antimicrobial agents are typically metabolized directly by the animal or its gastrointestinal microbiome, active residues may be excreted in the feces or urine leading to soil and water pollution in open environment (McAllister \& Topp, 2012; Sanderson et al., 2019). Lately, several studies are reporting increased isolation of obligatory or putative pathogenic bacteria in dairy cattle waste, including a diverse and altered microbiota profile enriched with potential human pathogens (Resende et al., 2014; Howard et al., 2017).

Anyway, the spread of microorganisms from intensive and extensive livestock operations is thought to be complex, and the arrival of these pathogens to adjacent water sources may happen through multiple pathways (McAllister \& Topp, 2012). The prevalence and levels of pathogens in the wastes are affected by several factors, such as animal race, diet, stress, age, or even grazing habits (Nicholson et al., 2005).

Microbial contamination of vegetables with manure or manure-contaminated water increases the chance of viable pathogens being consumed, especially in raw or low processed foods. Lack of sanitation and hygienic practices increase the chances of contamination. In this context, immunocompromised individuals are particularly susceptible to waterborne infections. In many cases, waterborne diseases that have been linked to cattle pathogens have been amplified as a result of person-to-person transmission (McAllister \& Topp, 2012). In order to show the implications of agricultural use of manure-based fertilizers, researchers have recently studied soil samples in the past 87 years, from 1923 to 2010. Data from this study showed, in soil fertilized by manure, that levels of antimicrobial resistance genes (ARG) such as $b l a_{\mathrm{TEM}}, b l a_{\mathrm{SHV}}$, and $b l a_{\mathrm{OXA}}$, which 
are related to beta-lactams-resistance, increased in the mid-1970s. Interestingly, at the same time, there were the first reports of these genes in clinical isolates from hospitals. Therefore, it is suggested that the ARG detected in soils might reflect a broader expansion throughout human society (nosocomial and community), implying that clinical and agricultural antibiotics and antimicrobial-resistance development are mutually influential (Graham et al., 2016). Proper manure handling in livestock operations is thought to be just one of the critical control points required to avoid foodborne illness and spread of ARG (McAllister \& Topp, 2012; Sanderson et al., 2019).

In the last 20 years, aquaculture in Brazil has been experiencing rapid expansion, and currently occupies a prominent position, contributing to job and income offers along the productive chain (Bueno et al., 2015). In Brazil, aquaculture regulation requires institutions that produce sectorial and social environmentally friendly standards, which lead to the implementation of policies and strategies that provide rational use of antimicrobials, protection against pollution, and recycling of water resources. However, aquaculture may result in important ecological impacts related to the destruction of natural habitats, deterioration of water quality, introduction of non-native species, and intensive use of chemical substances, such as antimicrobial agents and hormones in production systems (Cabello, 2006; Lima et al., 2018). For technical reasons, these compounds are introduced directly into the water as food components. Due to the high population densities of the species cultivated in each fish pond or space, it is difficult to quantify individual dosages, and a large number of antimicrobial agents is added (Baquero et al., 2008; Heuer et al., 2009).

In general, concerning resource management issues, water used in fish ponds is generally returned to the open environment following the original stream. When enriched with antimicrobials or antimicrobial-resistant putative human and animal pathogens, aquaculture might have an impact on the different associated ecosystems (Sanderson et al., 2019). Resistance genes are highly persistent and do not disappear or dissipate from aquaculture sites, even after several years without antimicrobial use (Tamminen et al., 2011; Resende et al., 2012). Although some scientific studies have already addressed these issues, there is still the need for more information on the impacts caused by fish farming systems, taking into account intrinsic and extrinsic characteristics of each farm.

\section{Factors Influencing Pathogen Proliferation and the Spread of Resistance Genes}

Since Alexander Fleming's discovery of penicillin, several antimicrobial drugs were discovered and revolutionized worldwide healthcare, becoming one of the most important medical advances of the $20^{\text {th }}$ century. As long as the key information to becoming drug-resistant has been with environmental bacteria (i.e., antimicrobial-resistance genetic determinants), the constant use and sometimes misuse of such medicines has lead the microbial evolution towards widespread resistance determinants, whose purpose is to allow bacterial strains to adapt to different selection pressures occurring in the environment (Mugnier et al., 2009).

Nowadays, antimicrobial resistance phenomena threaten many of the most important medical advances we have made. The understanding of various drivers of antibiotic resistance is the key to addressing the resistance problem, which includes their use in health care systems, environment, and agriculture and livestock. Additional important factors that are potent drivers of antibiotic resistance are sanitation settings, infection control standards, water hygiene systems, drug quality, diagnostics and therapeutics, and travel or migration quarantine (O’Neill, 2014; Aslam et al., 2018). The functional meta-genomic analysis of soil microbes has revealed an extensive diversity in genetic determinants associated with antibiotic resistance. In this scenario, there are the so-called genetic reservoirs, which are potential sites for genetic exchange and, hence, the spreading of potentially pathogenic bacteria due to high biological connectivity and the presence of specific selection (Baquero et al., 2008). Briefly, the emergence of resistance genes in the environment can happen in different ways, and in the aquatic environment, competition between different microorganisms for space and nutrients can be an important one. This happens when nonpathogenic, antibiotic-susceptible bacteria begin to produce antimicrobial substances in order to eliminate other microorganisms. The benefits of antibiotics for microbial producers are not entirely clear, but the explanation is that the producers use them as ecological weapons to inhibit neighboring competitors. In this sense, as these bacteria produce antimicrobial substances, resistance mechanisms are developed in order to gain adaptive advantage in 
the environment. Thus, susceptible non-pathogenic bacteria become resistant non-pathogenic bacteria, and these new resistance genes may occasionally be disseminated to other microbial groups, such as pathogenic bacteria to humans and other animals (Andersson \& Hughes, 2017). This spread occurs mainly in an environment with selective pressure (presence of antimicrobials, biocides, and heavy metals, among other xenobiotics) and by horizontal transfer mechanisms (conjugation, transduction, transformation, and also gene transfer agents). In addition, resistance acquisition can also occur in this environment by mutation, and pathogenic bacteria become resistant and can easily be spread across different ecological spheres (Bengtsson-Palme \& Larsson, 2015; Berglund, 2015).

An example is Kluyvera ascorbata, an environmental bacterium that had on its chromosome the $b l a_{\text {KLUA }}$ gene, which confers resistance to third-generation cephalosporins. In this particular case, due to the presence of a transposable genetic element (insertion sequence ISEcp1), it was possible to transpose the resistance gene from the Kluyvera to other bacteria species of concern, in either human or animal medicine (enterobacteria). This gene

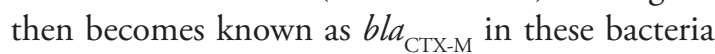
(Andersson \& Hughes, 2017). Clearly, the selective pressure imparted by the use of cephalosporins in humans and animals will increase the chance of the mobilization of $b l a_{\text {СтХ-м. }}$. In Brazil, the presence of this gene in isolates from commercial lettuce (Lopes et al., 2017) and in wild fish from Atlantic coast of South America was recently reported (Sellera et al., 2018). Developing countries with low levels of sanitation provide opportunities for the transfer between humans, animals, and the natural environment (Bevan et al., 2017).

As ARG may reach the aquatic environment through a variety of pathways, including anthropogenic activities; water bodies represent one of the most important ecosystems for antimicrobial resistance phenomenon. The aquatic environments have dynamic and distinct microbial composition patterns influenced by temporal and spatial unevenness in physicochemical and biotic factors, including environmental stresses and nutrient composition. As a consequence, antibiotic-resistant bacteria and their ARG may be directly influenced, altered, or amplified under selective pressures (Manyi-Loh et al., 2018).

While residues found in animal tissues may be directly related to the use of antimicrobials in the respective sector (cattle raising, pig farming, and poultry), these issues are more complicated with regards to aquaculture. Aquatic environments receive effluents from hospitals, animal farms, and agricultural field. Hence, antimicrobial-resistant bacteria are selected in other sectors, find their way into the aquatic environment, and may eventually reach aquaculture systems. Further ARG respect neither phylogenetic nor geographical borders, i.e. genetic markers selected in one sector may impact another. Gene transfer can be hindered or aided by ecological (e.g., resource availability, population density, and diversity) and environmental factors (e.g., heavy metal content, temperature, $\mathrm{pH}$, moisture content, and predation). When favorable conditions for bacterial growth and interrelationships are available in an open environment, gene transfer may occur at higher frequencies. In turn, the accumulation of ARG in an environment cannot be controlled by simply reducing the input of antimicrobials to the environment, as, once settled, ARG are not likely to be completely eliminated as a result of removal of the antimicrobial agent source. Additionally, ARG can be selected through selective pressure for other environmental stressors, such as heavy metals and temperature (Bengtsson-Palme \& Larsson, 2015; $\mathrm{Na}$ et al., 2018; Karkman et al., 2019).

In most developed countries, the use of antimicrobial agents in aquaculture and livestock is under regulatory oversight and should be done in consultation with a veterinarian (Sanderson et al., 2019). In undeveloped or developing countries, such as Brazil, concerns with possible human health impacts and recommendations of international references counseling for rational use of antimicrobials in animals are advised. In this regard, the Brazilian Ministry of Agriculture and Livestock has restricted the authorization of several antimicrobials. Since 1998, several drug classes and/or antimicrobial substances have been banned in Brazil, such as cloranfenicol (IN no 09, 27/06/2003), tetracyclines, penicillins, cephalosporins, quinolones, sulfonamides (IN no 26,9/07/2009), erythromycin, spiramycin (IN no 14, 17/05/2012) and, more recently, colistin (IN no 45, 22/11/2016). Apart from these governmental regulations, residues of antimicrobial drugs ( $\beta$-lactams, tetracyclines, quinolones, and sulfonamides) were recently found in milk marketed in Southwestern Brazil (Schlemper \& Sachet, 2017). In other countries, such as those that are low income and developing, including some African and Asian countries, persistent use of these antimicrobials 
may be attributed to the inadequate governmental policies and absence of legal control over their use and sale.

The technical recommendation for the management of wastes potentially related to putative pathogenic and antimicrobial-resistant bacteria or ARG include stockpiling/composting or treatment in lagoon storages for later release or use in crops as fertilizer (McAllister \& Topp, 2012). However, it is possible to consider that none of these treatments in use in Brazil or other developing/undeveloped countries are able to eliminate the final residue to the point of being released directly into the watercourses. Besides, different released antimicrobials do not all degrade at the same time, under the same treatment. According to their chemical characteristics, they should exhibit different rates of removal by processes such as sorption, photo degradation, biodegradation, and oxidation (Resende et al., 2014).

Lately, from a wider view, the One Health approach has been expanding to aquaculture production, using methods that may minimize risks to both public and animal health and open environment. In this way, healthy animal production systems should converge with efforts to reduce the risk for disease outbreaks to improve food security and human health (Cavalli et al., 2015). As one of the major consequences, resistance in bacteria causing human disease may arise either directly, via enrichment of these bacteria in the aquaculture environment, or indirectly, via enrichment of the genes that encode such resistance; and which may be transferred to bacteria associated with human disease. Besides that, there are concerns related to the adverse health effects associated with the presence of antimicrobial residues in the food. It is consensual that hazards related to animal disease, contamination, recontamination, or persistency of biological threats during processing can be controlled by applying approaches such as "Good Manufacturing Practice", "Good Hygiene Practice", and "Hazard Analysis and Critical Control Point" (Huss et al., 2000).

\section{Concluding Remarks}

The increasing scientific information that is widely observed has contributed, not only to new technologies, which have been incorporated in anthropogenic activities, and animal and environmental management, but also several social transformations. The open environment, which includes the interplay and connectivity between urban and natural areas, when considering soil and water, plays an important and central role in this scenario at community, healthy systems, and industrial levels. As a side effect, several concerns addressing how these technologies and social transformations are dealing to issues such as human health, microbiological safety, economy, and the social structure as a whole have been documented.

Overall, spreading of ARG through water and surrounding ecosystems is widely observed and not only considering antimicrobial chemotherapy at community and health treatments levels. The food production chain, the lack of universally applied practices in antibiotic stewardship, and effective environmental legislations are also highly related to the ARG occurrence and persistence in open environment. Besides that, the release of the medicines into the aquatic environment through leaching from unconsumed feeds and intentional or unintentional release of effluent water from aquaculture facilities and presence of residues in fecal materials are some of the environmental issues. The impacts on the local ecosystem are, in general, poorly studied. The ecological concerns should include accumulation of residues in the sediments, impacts of drugs and chemicals on indigenous biota, and possible development of antimicrobial resistance in aquatic bacteria.

Along with ARG, the presence of antimicrobialresistant bacteria or putative pathogenic microorganisms may lead to sanitary and ecological risks for the One Health approach, as it concerns the $21^{\text {st }}$ century. In the context of aquaculture, discussions are needed on occupational health seeking safe practices, in order to promote the health of the workers, the animals, and the shared work environment. Environmental regulations should address the sanitary and microbiological safety taking in account the interactions between our society (human behavior) and the environment regarding the persistence of putative pathogens and antimicrobial-resistant bacteria.

\section{References}

ANDERSSON, D.I. and HUGHES, D. Microbiological effects of sublethal levels of antibiotics. Nature Reviews. Microbiology, 2014, 12(7), 465-478. http:// dx.doi.org/10.1038/nrmicro3270. PMid:24861036.

ANDERSSON, D.I. and HUGHES, D. Selection and transmission of antibiotic-resistant bacteria. Microbiology Spectrum, 2017, 5(4). http://dx.doi. org/10.1128/microbiolspec.MTBP-0013-2016. PMid:28752817. 
ASLAM, B., WANG, W., ARSHAD, M.I., KHURSHID, M., MUZAMMIL, S., RASOOL, M.H., NISAR, M.A., ALVI, R.F., ASLAM, M.A., QAMAR, M.U., SALAMAT, M.K.F. and BALOCH, Z. Antibiotic resistance: a run down of a global crisis. Infection and Drug Resistance, 2018, 11, 1645-1658. http://dx.doi. org/10.2147/IDR.S173867. PMid:30349322.

BAQUERO, F., MARTÍNEZ, J.L. and CANTÓN, R. Antibiotics and antibiotic resistance in water environments. Current Opinion in Biotechnology, 2008, 19(3), 260-265. http://dx.doi.org/10.1016/j. copbio.2008.05.006. PMid:18534838.

BASTOS, M.C., SANTOS, D.R., AUBERTHEAU, É., LIMA, J.A.M.C., LE GUET, T., CANER, L., MONDAMERT, L. and LABANOWSKI, J. Antibiotics and microbial resistance in brazilian soils under manure application. Land Degradation \& Development, 2018, 29(8), 2472-2484. http://dx.doi. org/10.1002/ldr.2964.

BENGTSSON-PALME, J. and LARSSON, D.G.J. Antibiotic resistance genes in the environment: prioritizing risks. Nature Reviews. Microbiology, 2015, 13(6), 396. http://dx.doi.org/10.1038/ nrmicro3399-c1. PMid:25915637.

BERGLUND, B. Environmental dissemination of antibiotic resistance genes andcorrelation to anthropogenic contamination with antibiotics. Infection Ecology \& Epidemiology, 2015, 5(1), 28564. http://dx.doi.org/10.3402/iee.v5.28564. PMid:26356096.

BEVAN, E.R., JONES, A.M. and HAWKEY, P.M. Global epidemiology of CTX-M $\bigotimes$-lactamases: temporal and geographical shifts in genotype. The Journal of Antimicrobial Chemotherapy, 2017, 72(8), 2145-2155. http://dx.doi.org/10.1093/jac/dkx146. PMid:28541467.

BRASIL. Ministério da Agricultura, Pecuária e Abastecimento. Sumário executivo: carnes [online]. Brasília, 2018 [viewed 7 Dec. 2018]. Available from: http://www.agricultura.gov.br/assuntos/politicaagricola/todas-publicacoes-de-politica-agricola/ sumarios-executivos-de-produtos-agricolas/carnes. $\mathrm{pdf} / \mathrm{view}$

BROWN, K., UWIERA, R.R.E., KALMOKOFF, M.L., BROOKS, S.P.J. and INGLIS, G.D. Antimicrobial growth promoter use in livestock: a requirement to understand their modes of action to develop effective alternatives. International Journal of Antimicrobial Agents, 2017, 49(1), 12-24. http:// dx.doi.org/10.1016/j.ijantimicag.2016.08.006. PMid:27717740.

BUENO, G.W., OSTRENSKY, A., CANZI, C., DE MATOS, F.T. and ROUBACH, R. Implementation of aquaculture parks in Federal Government waters in Brazil. Reviews in Aquaculture, 2015, 7(1), 1-12. http://dx.doi.org/10.1111/raq.12045.
CABELLO, F.C. Heavy use of prophylactic antibiotics in aquaculture: a growing problem for human and animal health and for the environment. Environmental Microbiology, 2006, 8(7), 1137-1144. http:// dx.doi.org/10.1111/j.1462-2920.2006.01054.x. PMid:16817922.

CAVALLI, L.S., BRITO, K.C.T. and BRITO, B.G. One Health, One Aquaculture: aquaculture under one health umbrella. Journal of Marine Biology and Aquaculture, 2015, 1(1), 1-2. http://dx.doi. org/10.15436/2381-0750.15.005.

COLLIGNON, P. and MCEWEN, S.A. One Health: its importance in helping to better control antimicrobial resistance. Tropical Medicine and Infectious Disease, 2019, 4(1), 22. http://dx.doi.org/10.3390/ tropicalmed4010022. PMid:30700019.

COlOMBO, S., ARIOli, S., NERI, E., DELlA SCALA, G., GARGARI, G. and MORA, D. Viromes as genetic reservoir for the microbial communities in aquatic environments: a focus on antimicrobialresistance genes. Frontiers in Microbiology, 2017, 8, 1095. http://dx.doi.org/10.3389/fmicb.2017.01095. PMid:28663745.

CONTE, D., PALMEIRO, J.K., NOGUEIRA, K. S., LIMA, T.M., CARDOSO, M.A., PONTAROLO, R., DEGAUT PONTES, F.L. and DALLA-COSTA, L.M. Characterization of CTX-M enzymes, quinolone resistance determinants, and antimicrobial residues from hospital sewage, wastewater treatment plant, and river water. Ecotoxicology and Environmental Safety, 2017, 136, 62-69. http://dx.doi.org/10.1016/j. ecoenv.2016.10.031. PMid:27816836.

D'COSTA, V.M., MCGRANN, K.M., HUGHES, D.W. and WRIGHT, G.D. Sampling the antibiotic resistome. Science, 2006, 311(5759), 374-377. http://dx.doi.org/10.1126/science.1120800. PMid:16424339.

EWERS, C., BETHE, A., SEMMLER, T., GUENTHER, S. and WIELER, L.H. Extended-spectrum betalactamase-producing and AmpC-producing Escherichia coli from livestock and companion animals, and their putative impact on public health: a global perspective. Clinical Microbiology and Infection, 2012, 18(7), 646-655. http:// dx.doi.org/10.1111/j.1469-0691.2012.03850.x. PMid:22519858.

FINLEY, R.L., COLLIGNON, P., LARSSON, D.G., MCEWEN, S.A., LI, X.Z., GAZE, W.H., REIDSMITH, R., TIMINOUNI, M., GRAHAM, D.W. and TOPP, E. The scourge of antibiotic resistance: the important role of the environment. Clinical Infectious Diseases, 2013, 57(5), 704-710. http:// dx.doi.org/10.1093/cid/cit355. PMid:23723195.

GONZALEZ RONQUILLO, M. and ANGELES HERNANDEZ, J.C. Antibiotic and synthetic growth promoters in animal diets: Review of impact and analytical methods. Food Control, 
2017, 72, 255-267. http://dx.doi.org/10.1016/j. foodcont.2016.03.001.

GRAHAM, D.W., KNAPP, C.W., CHRISTENSEN, B.T., MCCLUSKEY, S. and DOLFING, J. Appearance of $\beta$-lactam resistance genes in agricultural soils and clinical isolates over the 20(th) century. Scientific Reports, 2016, 6(1), 21550. http:// dx.doi.org/10.1038/srep21550. PMid:26878889.

GROS, M., RODRÍGUEZ-MOZAZ, S. and BARCELÓ, D. Fast and comprehensive multi-residue analysis of a broad range of human and veterinary pharmaceuticals and some of their metabolites in surface and treated waters by ultra-high-performance liquid chromatography coupled to quadrupole-linear ion trap tandem. Journal of Chromatography $A$, 2012, 1248, 104-121. http://dx.doi.org/10.1016/j. chroma.2012.05.084. PMid:22704668.

HEUER, H., SCHMITT, H. and SMALLA, K. Antibiotic resistance gene spread due to manure application on agricultural fields. Current Opinion in Microbiology, 2011, 14(3), 236-243. http://dx.doi. org/10.1016/j.mib.2011.04.009. PMid:21546307.

HEUER, O.E., KRUSE, H., GRAVE, K., COLLIGNON, P., KARUNASAGAR, I. and ÂNGULO, F.J. Human health consequences of use of antimicrobial agents in aquaculture. Clinical Infectious Diseases, 2009, 49(8), 1248-1253. http://dx.doi.org/10.1086/605667. PMid:19772389.

HOWARD, K.J., MARTIN, E., GENTRY, T., FEAGLEY, $S$. and KARTHIKEYAN, R. Effects of dairy manure management practices on E. coli concentration and diversity. Water, Air, and Soil Pollution, 2017, 228(1), 4. http://dx.doi.org/10.1007/s11270-016-3182-7.

HUSS, H.H., REILlY, A. and EMBAREK, P.K.B. Prevention and control of hazards in seafood. Food Control, 2000, 11(2), 149-156. http://dx.doi. org/10.1016/S0956-7135(99)00087-0.

KARKMAN, A., PÄRNÄNEN, K. and LARSSON, D.G.J. Fecal pollution can explain antibiotic resistance gene abundances in anthropogenically impacted environments. Nature Communications, 2019, 10(1), 80. http://dx.doi.org/10.1038/s41467018-07992-3. PMid:30622259.

LIMA, L.B., OLIVEIRA, F.J.M., GIACOMINI, H.C. and LIMA囚JUNIOR, D.P. Expansion of aquaculture parks and the increasing risk of nonØnative species invasions in Brazil. Reviews in Aquaculture, 2018, 10(1), 111-122. http://dx.doi. org/10.1111/raq. 12150.

LOPES, R., CERDEIRA, L.T., FERNANDES, M.R., PÉREZ-CHAPARRO, P.J., MCCULLOCH, J.A. and LINCOPAN, N. Draft genome sequence of a CTX-M-15-producing endophytic Klebsiella pneumoniae ST198 isolate from commercial lettuce. Journal of Global Antimicrobial Resistance, 2017, 10, 19-20. http://dx.doi.org/10.1016/j. jgar.2017.03.005. PMid:28576742.
MAGALHÁES, M.J.T.L., PONTES, G., SERRA, P.T., BALIEIRO, A., CASTRO, D., PIERI, F.A., CRAINEY, J.L., NOGUEIRA, P.A. and ORLANDI, P.P. Multidrug resistant Pseudomonas aeruginosa survey in a stream receiving effluents from ineffective wastewater hospital plants. BMC Microbiology, 2016, 16(1), 193. http://dx.doi.org/10.1186/s12866-0160798-0. PMid:27558582.

MANAIA, C.M., MACEDO, G., FATTA-KASSINOS, D. and NUNES, O.C. Antibiotic resistance in urban aquatic environments: can it be controlled? Applied Microbiology and Biotechnology, 2016, 100(4), 15431557. http://dx.doi.org/10.1007/s00253-015-72020. PMid:26649735.

MANYI-LOH, C., MAMPHWELI, S., MEYER, E. and $\mathrm{OKOH}, \mathrm{A}$. Antibiotic use in agriculture and its consequential resistance in environmental sources: potential public health implications. Molecules, 2018, 23(4), 795. http://dx.doi.org/10.3390/ molecules23040795. PMid:29601469.

MARTI, E., VARIATZA, E. and BALCAZAR, J.L. The role of aquatic ecosystems as reservoirs of antibiotic resistance. Trends in Microbiology, 2014, 22(1), 3641. http://dx.doi.org/10.1016/j.tim.2013.11.001. PMid:24289955.

MCALLISTER, T.A. and TOPP, E. Role of livestock in microbiological contamination of water: commonly the blame, but not always the source. Animal Frontiers, 2012, 2(2), 17-27. http://dx.doi.org/10.2527/ af.2012-0039.

MUGNIER, P.D., POIREL, L., NAAS, T. and NORDMANN, P. Worldwide dissemination of the bla OXA-23 carbapenemase gene of Acinetobacter baumannii. Emerging Infectious Diseases, 2009, 16(1), 35-40. http://dx.doi.org/10.3201/eid1601.090852. PMid:20031040.

NA, G., LU, Z., GAO, H., ZHANG, L., LI, Q., LI, R., YANG, F., HUO, C. and YAO, Z. The effect of environmental factors and migration dynamics on the prevalence of antibiotic-resistant Escherichia coli in estuary environments. Scientific Reports, 2018., 8(1), 1663. PMid:29374235.

NICHOLSON, F.A., GROVES, S.J. and CHAMBERS, B.J. Pathogen survival during livestock manure storage and following land application. Bioresource Technology, 2005, 96(2), 135-143. http://dx.doi.org/10.1016/j. biortech.2004.02.030. PMid:15381209.

O'NEILL, J. Review on antimicrobial resistance: antimicrobial resistance: tackling a crisis for the health and wealth of nations. London: UK Government and the Wellcome Trust, 2014 [viewed 19 Oct. 2019]. Available from: https://amr-review.org/ sites/default/files/AMR\%20Review\%20Paper\%20 -\%20Tackling $\% 20$ a $\% 20$ crisis $\% 20$ for $\% 20$ the $\% 20$ health $\% 20$ and $\% 20$ wealth $\% 20$ of $\% 20$ nations_1.pdf

OGAWA, V.A., SHAH, C.M., HUGHES, J.M. and KING, L.J. Prioritizing a one health approach in 
the immediate fight against antimicrobial resistance. EcoHealth, 2019, 16(3), 410-413. PMid:29524056.

RESENDE, J.A., SILVA, V.L., FONTES, C.O., SOUZA-FILHO, J.A., OLIVEIRA, T.L.R., COELHO, C.M., CÉSAR, D.E. and DINIZ, C.G. Multidrug-resistance and toxic metal tolerance of medically important bacteria isolated from an aquaculture system. Microbes and Environments, 2012, 27(4), 449-455. http://dx.doi.org/10.1264/ jsme2.ME12049. PMid:22972388.

RESENDE, J.A., SILVA, V.L., OLIVEIRA, T.L.R., FORTUNATO, S.O., CARNEIRO, J.C., OTENIO, M.H. and DINIZ, C.G. Prevalence and persistence of potentially pathogenic and antibiotic resistant bacteria during anaerobic digestion treatment of cattle manure. Bioresource Technology, 2014, 153, 284-291. http://dx.doi.org/10.1016/j.biortech.2013.12.007. PMid:24374028.

ROUSHAM, E.K., UNICOMB, L. and ISLAM, M.A. Human, animal and environmental contributors to antibiotic resistance in low-resource settings: integrating behavioral, epidemiological and One Health approaches. BProceedings of the Royal Society B: Biological Sciences, 2018, 285(1876), 20180332. http://dx.doi.org/10.1098/rspb.2018.0332.

SANDERSON, H., BROWN, R.S., HANIA, P., MCALLISTER, T.A., MAJURY, A. and LISS, S.N. Antimicrobial resistant genes and organisms as environmental contaminants of emerging concern: addressing global public health risks. In: B. ROIG, K. WEISS and V. THIREAU, eds. Management of emerging public health issues and risks: multidisciplinary approaches to the changing environment. London: Academic Press Elsevier, 2019, pp. 147-187. http:// dx.doi.org/10.1016/B978-0-12-813290-6.00007-X.

SCHAUSS, T., GLAESER, S.P., GÜTSCHOW, A., DOTT, W. and KÄMPFER, P. Improved detection of extended spectrum beta-lactamase (ESBL)-producing Escherichia coli in input and output samples of German biogas plants by a selective pre-enrichment procedure. PLoS One, 2015, 10(3), e0119791. http:// dx.doi.org/10.1371/journal.pone.0119791.

SCHLEMPER, V. and SACHET, A.P. Antibiotic residues in pasteurized and unpasteurized milk marketed in southwest of Paraná, Brazil. Ciência Rural, 2017, 47(12), e20170307. http://dx.doi. org/10.1590/0103-8478cr20170307.

SELLERA, F.P., FERNANDES, M.R., MOURA, Q., CARVALHO, M.P. and LINCOPAN, N. Extendedspectrum- $\beta$-lactamase (CTX-M)-producing Escherichia coli in wild fishes from a polluted area in the Atlantic Coast of South America. Marine Pollution Bulletin, 2018, 135, 183-186. http:// dx.doi.org/10.1016/j.marpolbul.2018.07.012. PMid:30301029.

TAMMINEN, M., KARKMAN, A., LOHMUS, O., MUZIASARI, W.I., TAKASU, H., WADA, S., SUZUKI, S. and VIRTA, M. Tetracycline resistance genes persist at aquaculture farms in the absence of selection pressure. Environmental Science of Technology, 2011, 45(2), 386-391. http://dx.doi. org/10.1021/es102725n. PMid:21158437.

VAN BOECKEL, T.P., BROWER, C., GILBERT, M., GRENFELL, B.T., LEVIN, S.A., ROBINSON, T.P., TEILLANT, A. and LAXMINARAYAN, R. Global trends in antimicrobial use in food animals. Proceedings of the National Academy of Sciences of the United States of America, 2015, 112(18), 56495654. http://dx.doi.org/10.1073/pnas.1503141112. PMid:25792457.

WEBSTER, J.P., GOWER, C.M., KNOWLES, S.C., MOLYNEUX, D.H. and FENTON, A. One Health: an ecological and evolutionary framework for tackling Neglected Zoonotic Diseases. Evolutionary Applications, 2016, 9(2), 313-333. http://dx.doi. org/10.1111/eva.12341. PMid:26834828.

ZHANG, X., ZHANG, T. and FANG, H.H.P. Antibiotic resistance genes in water environment. Applied Microbiology and Biotechnology, 2009, 82(3), $397-$ 414. http://dx.doi.org/10.1007/s00253-008-1829-z. PMid:19130050.

Received: 25 April 2019 Accepted: 28 February 2020

Associate Editors: André Megali Amado, Joyce Andreia dos Santos, Rafael Marques Almeida, Simone Jaqueline Cardoso. 